\title{
Informal community-based early childhood development as a focus for urban public theology in South Africa
}

Authors:

J.P. (Hannes) van der Walt ${ }^{1}$

Ignatius Swart ${ }^{2}$

Stephan de Beer ${ }^{1}$

Affiliations:

${ }^{1}$ Centre for Contextual Ministry, Faculty of Theology,

University of Pretoria,

South Africa

${ }^{2}$ Research Institute for Theology and Religion, University of South Africa, South Africa

\section{Note:}

This article forms part of the special collection on 'Doing urban public theology in South Africa: Visions, approaches, themes and practices towards a new agenda' in HTS Teologiese Studies/Theological Studies Volume 70, Issue 3, 2014. The collection is the result of the project 'Urban Public Theology', which was initiated by the Institute for Urban Ministry but later expanded to include several academic departments and institutes at the University of Pretoria (UP) and University of South Africa (UNISA).

The leading centres in this regard were the Centre for Contextual Ministry (UP) and the Research Institute for Theology and Religion (UNISA).

Correspondence to: Ignatius Swart

Email:

swarti1@unisa.ac.za

Postal address:

PO Box 329, University of South Africa, Pretoria 0003 South Africa

Read online:
This article highlights important dimensions of public theology and shows how the identified dimensions are relevant to the specific situation of informal early childhood development (ECD) facilities in a South African urban setting. The article considers the contributions and challenges of informal community-based ECD on the basis of research conducted in the Rustenburg/Phokeng area of the North West province of South Africa. It critically discusses the sociocultural discourses and legislation regulating ECD centres, by focusing on the constraints put on informal ECD service providers. It concludes by considering ways in which urban public theology should act to serve, strengthen and advocate this vitally important, yet informal, sector.

\section{Introduction}

The aim of this article is twofold: to highlight important dimensions of public theology, and show how the identified dimensions are relevant to the specific situation of informal ECD facilities in a South African urban setting.

The article begins with a discussion of concepts and ideas that are considered to be relevant to the notion of 'urban public theology'. This is done with reference to aspects that were discussed in two recent publications by South African theological scholars. The role of public theology in identifying and, where necessary, deconstructing different levels of narrative or discourse in society are highlighted, along with a specific identification of different modes of public theology in one of the publications. In view of such a public theological undertaking the article then shifts its attention to the more specific contextual issue of ECD in South African society. In particular, in this topical focus, attention is given to the 'societal mind' of the broad South African community as reflected by different levels or manifestations of sociocultural discourse. This, firstly, pertains to discourses in policy, law and scientific labour that confirm the social importance of ECD; secondly to discourses in policy and law that threaten the existence of an important section of the ECD community; and, thirdly, to narratives on personal and organisational level that reflect stories of suffering and despair, but also of resilience and hope (cf. Koopman 2009:117, 130) amongst members of this community. All of this is discussed in relation to the striving of communities to take care of their own children, which leads the article to finally consider ways in which an urban public theology should serve, strengthen and advocate with this vitally important, yet informal, sector.

\section{Doing urban public theology}

This article, in its understanding of 'urban public theology', utilises concepts and ideas that were well presented in two recently published articles.

The first by De Villiers and De Beer (2009) advocated the idea that public theology needs, at least to some extent, to grow out of the narrative structure of communities. By way of example, the article shows how an understanding of the narrative structure of a specific community downtown Pretoria/Tshwane in the Gauteng province of South Africa - was applied as part of a public theological process to influence urban policy and make an impact on real-life issues in the city. Three levels of narrative discourse were distinguished: multiple personal or individual narratives, organisational narratives, and grand narratives, that is sociocultural discourses, that

Dates: Received: 18 June 2014 | Accepted: 19 July 2014 | Published: 20 Nov. 2014

How to cite this article: Van der Walt, J.P., Swart, I. \& De Beer, S., 2014, 'Informal community-based early childhood development as a focus for urban public theology in South Africa', HTS Teologiese Studies/Theological Studies 70(3), Art. \#2769, 16 pages. http://dx.doi. org/10.4102/hts.v70i3.2769

Copyright: @ 2014. The Authors. Licensee: AOSIS OpenJournals. This work is licensed under the Creative Commons Attribution License. 
affect policies applying to the area where people live and work (De Villiers \& De Beer 2009:132). The implication of the approach advocated by the article is that, in order to bring hope to a situation of hopelessness, it is often necessary to deconstruct the different levels of (urban) narrative discourse and to oppose policies and strategies that prevent the realisation of vision.

Sensitivities that a Christian urban public theology has to take into account are identified in the article. This includes, that well-meant development support could intensify the crises it is meant to alleviate (De Villiers \& De Beer 2009:117). These and other sensitivities call for a public theological response that will enable the grass roots stories of individuals and institutions from communities to be heard, and the grand narratives or societal discourses that function in communities and amongst policy-makers and administrators to be evaluated and deconstructed (De Villiers \& De Beer 2009:127). A proper awareness of the individual and communal narratives on various levels should inform processes of responsible policy development and crafting of strategies, in cities and elsewhere.

One of the dilemmas that an urban public theology is confronted with is to discern when to engage in a positive, constructive and supportive role vis-à-vis problematic policy and administrative positions, and when to be critical and to oppose, to challenge prophetically and to boycott (De Villiers \& De Beer 2009:127). For that matter, even to engage in civil disobedience by deliberately disregarding unjust aspects of the regulatory system.

Indeed, there may be times when drastic measures such as the ones identified by De Villiers and De Beer are called for. An element of the regulatory system that is for instance very relevant to the urban situation is that of municipal building regulations. In their article De Villiers and De Beer confirm that in the urban development project they reported on, municipal regulations and standards conforming to aesthetical agreeability, thoroughness and legality were adhered to. Yet, later in this article it will be argued that those same regulations and standards sometimes create a situation that is not tolerable and, as a result, calls for the discourses on which they are based to be deconstructed so that more appropriate regulations and standards in terms of policy and law can be devised. In this article it is proposed that such evaluation and, if necessary, deconstruction of discourses and opposition to oppressive urban development policies in view of more appropriate policy-making should be indissolubly part of the public theological task.

A complementary approach to public theology is provided by Nico Koopman (2009) in an article on an expanded understanding of the function of public theology. Agencies of the Christian religion that are serious about the missio Dei - which implies a thorough understanding of the Trinitarian character of the Christian faith - will strive to play a constructive role in society. For this to happen, thorough theological labour is crucial. The discipline of public theology grows out of such understanding of the need for theological labour to reflect scientifically on the content of the Christian Trinitarian faith, the rationality of this faith and the impact and implication of this faith (Koopman 2009:119-120).

With reference to, but also through an adaption of, distinctions that were made by James Gustafson, a prominent American theological ethicist of the 20th century, Koopman continues by proposing that the public relevance of the Christian faith in democratic South Africa be worked out in five modes of prophetic speaking (Koopman 2009:120-121). According to Koopman, two of the proposed modes are popular and often applied, namely 'vision of the good society' (utopianism) and 'criticism'. Together, both modes represent the more traditional understanding of prophetic speaking. Prophets as visionaries use utopian language, symbols, analogies and metaphors that not only inspire their hearers towards new visions of hope amidst suffering and despair, but in the process also move them to work for the realisation of the proclaimed visions, 'albeit in imperfect, penultimate forms' (Koopman 2009:121-122); and in their role as critics, they 'perform the task of denouncing the reality that is in conflict with the vision of a new society'. Through their criticism they get 'to the roots of problems that pervade institutions and cultures, or that pervade the actions and behaviour of individual persons' (Koopman 2009:122). Whilst '(t)hey do not engage in detailed policy recommendations', or in 'matters of strategy and tactics', their critical pronouncements play an important role in guarding 'against inappropriate compromises, decisions and policies that would betray the most vulnerable' (Koopman 2009:122-123).

Yet, for Koopman, more than utopian and critical speaking is required in the context of contemporary South African society. To be true to life and to ensure that the prophetic task 'be fulfilled in a more faithful and credible way' (Koopman 2009:121), the former two modes need to be complemented by the following three supplementary modes as constituent elements of an integrated, richer and more comprehensive prophetic vocation: story-telling, technical analysis and policy-making (Koopman 2009:120-121).

Concerning the first of these three supplementary modes, stories or narratives could be appreciated for the way in which they may reveal 'features of life that are somehow excluded from technical abstract casuistry' (Koopman 2009:124). While stories 'do not offer theories of justice or injustice' they 'do have a moving prophetic effect', especially through the way in which they reveal the real-life experiences of poor and oppressed people (Koopman 2009:124-125). As such they may advance 'the quest to address wrongs in the world theologically and confessionally' (Koopman 2009:125).

Concerning the second of the supplementary modes, technical analysis, prophetic speaking implies 'a more precise use of concepts like justice, virtue, rights and duties'. For this to happen, 'stronger logical arguments' are needed 'in support 
of moral descriptions or moral condemnations' (Koopman 2009:125). However, this can only be achieved through an application of different ethical theories that complement each other. This mode of speaking, therefore, conforms to a high level of technical, ethical and philosophical discourse, in order 'to translate the passionate pleas of the prophet into rationally defensible public positions' that may potentially make an impact on the formation of public opinion, public ethos and ultimately public policy (Koopman 2009:126).

Lastly, whereas it could be said that the four modes discussed so far all function with the external perspective of an observer, the fifth identified mode of policy engagement functions instead with the internal perspective of persons and agents who are required to make choices and give directions in complex and specific circumstances. Given this particularity, the act of policy-making operates within the confines of limited and actual possibilities of action, for which it is reliant on the assistance of sociological, economic and other disciplinary concepts. Yet, despite this confinement, and despite the fact that within the policy-making process the ethical is not the only consideration from the position of Christian public speaking in the prophetic mould, a variety of vulnerable people are given priority, 'amongst others children, women, oppressed racial groups, poor people and exploited workers' (Koopman 2009:127-128). Koopman (2009), in this regard, elaborates:

This notion of the priority of the most vulnerable will help so that the unavoidable compromises will not impact negatively on them. This notion of the option of the most vulnerable serves as a benchmark with regard to policymaking and especially the adoption of compromises. (p. 128)

The various dimensions of public theology highlighted in this section of the article provide a useful framework for a reflection on the possible public role of Christian theology and the Church in the sphere of ECD discourse and practice in urban South Africa; although the emphasis here on the urban may be taken to be just as relevant to the rural areas of the country. With this in mind, the discussion now more pertinently shifts its attention to the specific contextual issue of ECD in South Africa.

\section{Sociocultural discourses confirming the importance of early childhood development}

With social-cultural discourses are meant the way that the 'societal mind' thinks about and responds to matters of importance in the community. The societal mind is influenced by the widely accepted beliefs and values of society, and is socially and culturally constructed (cf. Bons-Storm 1996; Mercer 2004).

The character of the societal mind with its underlying sociocultural discourses can inter alia be known from a society's documents of science, policy and law. Based on this recognition, there seems to be a wide acknowledgement of the importance of a child's early developmental stages in the South African societal mind as reflected in its documents of science, policy and law (Martin et al. 2014a:15-18; Richter et al. 2014:17-28, Appendix 5).

South Africa is a signatory to the United Nations' Convention on the Rights of the Child, and the African Charter on the Rights and Welfare of the Child. Children's rights have also been enshrined in the South African Constitution (Constitution of the Republic of South Africa No. 108 of 1996, Section 28; Swart \& Yates 2006:323-324; Yates 2012:104-107; cf. Martin et al. 2014a:15-16). Although the Constitution does not explicitly refer to ECD, the way in which the rights of children are formulated is widely interpreted as a confirmation of the importance of the early phases of life (see e.g. City of Cape Town 2013:11). Section 28(1) of the Constitution formulates the right of children to basic nutrition, shelter, health care services and social services, and confirms the child's right to be protected from maltreatment, neglect, abuse and degradation. In South Africa, ECD is dealt with primarily as a social service issue regulated under social development policy and legislation, and not primarily under educational policy and law. In this sense the constitutional right to 'social services' and protection against neglect can be interpreted as recognition by the Constitution of the essential importance of decent early childhood services.

The constitutional recognition of the duty of communities to proper care for the young child has been matched by the vast growth of literature on this topic in South Africa in recent years. During the last two decades more than 120 scientific and policy documents related to ECD were published in this country (Richter et al. 2014:2, Appendix 5; cf. Martin et al. 2014a:15-18). Of particular importance is the variety of policy statements and pieces of legislation that appeared since 1995, amongst others the National Programme of Action for Children in South Africa (1996), White Paper 5 on Early Childhood Development (2001), the National Integrated Plan for ECD 2005 - 2010, the Diagnostic Review of ECD (2012), and the National Plan of Action for Children in South Africa 2012-2017 (Martin et al. 2014a:16-17; Richter et al. 2014:18, 21-26, Appendix 5). Furthermore, a major step was the promulgation of the Children's Act 38 of 2005 and, more specifically, the Children's Amendment Act 41 of 2007, which contains two chapters that directly impact on ECD. Chapter 5 regulates the physical aspects of ECD and other partial care services, and Chapter 6 deals with the educational contents and regulatory framework of ECD services (The Presidency, Republic of South Africa 2008).

One of the more recent contributions confirming the importance attached to ECD in the societal mind is the widely acclaimed National Development Plan 2030 (NDP) produced in 2011 by the National Planning Commission (NPC). In the NDP's emphasis on education as foundational to the kind of equitable, flourishing society it envisions for the country (NPC 2011:295-328), the critical importance of ECD 'for children to reach their full potential' is highlighted (NPC 2011:297; cf. Martin et al. 2014a:18; Richter et al. 2014:19-21). 
For this reason, it becomes significant to note how the NDP states in its list of recommendations that ECD should become 'a top priority amongst the measures to improve the quality of education and long-term prospects of future generations' (NPC 2011:300). For the NDP this furthermore entails that:

- Dedicated resources should be channelled towards ensuring that children are well cared for from an early age and that they receive the necessary emotional, cognitive and physical development stimulation.

- The definition of ECD should be broadened to take into account all the development needs of a child.

- Two years of quality preschool enrolment for four and five year olds before Grade 1 should be made compulsory.

- A comprehensive package of services should be defined and phased in for all young children.

- Coordination weaknesses between the different sectors and departments responsible for ECD services should be addressed in order to strengthen collaboration.

- The guidelines, norms and standards for ECD programmes should be standardised.

- Innovation in the way ECD services are delivered should be encouraged, entailing amongst others that home and community-based ECD interventions should be piloted in selected districts (NPC 2011:300-301).

It could be concluded that the recognition given to ECD in the NDP, policy documentation and the law is indicative of an ever-growing recognition by the South African educational and social development community of the importance of the early phases of a child's development. This recognition, which places ECD on a level of importance equal to schooling, tertiary education and vocational training (NPC 2011:295-328), seems to become more and more part of the overarching sociocultural discourse that underlies policies and laws on ECD. Not least, this could be seen today in the vast number of community-based ECD facilities being established, the growth in ECD training facilities, the extent of research and publication of scientific articles, the extent of policy development focused on this topic, the detailed attention given in legislation to this issue, and the importance attached to this function in the NDP.

\section{Sociocultural discourses limiting the rights of communities to provide their own essential services}

Despite the growing appreciation of ECD as a determinant of individual and community well-being in South African communities, it is, however, still not 'all systems go' for this discipline and profession. Large backlogs remain in resource-poor communities, and there are serious limitations in so far as the ability of government and the formal nongovernmental organisations (NGO) sector is concerned to provide the kind of services that the rights of children and educational wisdom actually demand (cf. NPC 2011:299). At the same time, amidst these realities communities are not actively encouraged to assume responsibility for themselves.
On the contrary, they are to a large extent hampered and discouraged to take care of their own well-being because of the way policy and legislation is formulated and applied. The discouraging factors are based on grand narratives or discourses in society that need to be identified, evaluated and, where necessary, deconstructed.

Information provided later in this article testifies to large backlogs in the provision of the relevant services by government. For example, in the North West province which is the province where the empirical study reported on later in the discussion was executed - statistics show that approximately only $30 \%$ of children were cared for in formal or registered facilities. For all practical purposes, it can be assumed that government will not be in a position to bring about more than a marginal improvement of the present situation, and that the gap in the current provision of ECD services will as a result not be sufficiently closed.

The fact remains that the current deficiency in the delivery of ECD services has to be addressed in accordance with what the constitutional rights of South Africa's children and the logic of educational and community development demand. But who will do this? The answer is not an easy one as there are many challenges everywhere. But an important part of the answer is at least to allow communities to do the best they can if nobody else is going to do it for them. Which brings us to the crucial question: are communities in South Africa allowed to do the best they can to develop their own solutions if nothing better is provided?

\section{Contradictory positions in the regulatory framework}

\section{The Children's Act at a first glance}

A survey of the policy and regulatory environment surrounding ECD facilities in South Africa reveals contradictory positions. To a large extent it can be said that, in the case of social development laws, the legislature has been sensitive to the difficult realities that some communities have to contend with. Perusal of the relevant legislation with specific reference to the already mentioned Children's Act and its regulations on ECD - reveals sensitivity for the financial and resource related stresses experienced by many of the informal ECD facilities in poverty-stricken areas. The Act clearly sets fairly high standards in its regulatory framework. Yet, at the same time, it also shows sensitivity for the reality that there will be communities and facilities that provide a good service, but that find it impossible to reach the ideal physical standards as spelt out by the Act. The principle seems to be that high standards are set as the ideal, whilst precaution is taken to always act in the best interest of the child, even if it would in some cases mean that lower standards are condoned instead of merely closing down facilities and leaving children with even weaker (or no) alternative care. The following provisions are examples of this more lenient position displayed in the Children's Act: 
- The Act provides for the possibility that exemption from the requirement to register may be given to individual facilities or categories of facilities (The Presidency, Republic of South Africa 2008, Section 80(2)).

- The Act enables the provincial department to conditionally register a facility (2008, Section 83 ). This implies that a facility experiencing challenges should not be closed down summarily (or have their registration withheld), but that opportunity should be given for improvements that may be required.

- The Act enables the minister to assist a facility that does not comply with the requirements towards compliance (2008, Section 82(5)).

- In considering applications for funding of a facility, the principle is that facilities in poorer communities should be prioritised (2008, Sections 78(4) and 93(4)).

- The way in which the Minister of Social Development has under Section 306 of the Children's Act (Department of Social Development 2010:2) formulated the regulations dealing with national standards for these services creates space for facilities that experience physical and financial challenges to apply principles without expecting adherence to rigid prescriptions that are often impossible to reach. Typical formulations used in the regulations are, for example, ' $[w]$ here possible, children must be separated in ... age categories in different rooms ...' (Department of Social Development 2010:110); and, ' $r$ ] easonable precautions to protect children from risk of fire, accidents and other hazards must be taken' (2010:111). Such formulations leave room for creative solutions without being caught up in rigid 'letter of the law' requirements.

\section{The Children's Act at a second glance}

If the above-mentioned relatively lenient inclinations of the Children's Act would have represented the full story of how policy, laws and administrative processes deal with ECD in poverty-stricken areas in South Africa, there would be fewer problems. Unfortunately this is not the case: the sensitivity for difficult realities that was referred to above, as revealed in parts of the Children's Act and regulations, does not appear to be the norm throughout. The following observations may suffice to illustrate the point:

- The Act defines non-compliance with the registration requirements as an offence, which is understandable considering how the law functions (The Presidency, Republic of South Africa 2008, Section 305(1)(f)). Nonetheless, this regulation can be considered as extremely harsh if it is taken into account that people who assume responsibility for children under the most trying circumstances, are summarily being criminalised for the care they provide to the most vulnerable ones of the community.

- The Children's Act also relies on the much more rigid urban or local authority regulatory framework as a prerequisite for the registration of a facility. This becomes clear from the stipulation in Section 78(2)(b)(ii) of the
Act that determines that a facility must comply with the structural safety, health and other requirements of the municipality of the area where the facility is situated. Similarly, it also becomes clear from a formulation in the Department of Social Development's consolidated regulations with regard to the Children's Act, which states that 'new buildings and alterations to buildings must comply with the building standards as set out by the National Building Regulations and Building Standard Act' (Department of Social Development 2010:108).

These requirements are understandable when one considers the way the regulatory framework in cities works. But, if the way that cities work leads to the criminalisation of people who care for the vulnerable ones where neither government nor anyone else can do so, something is clearly wrong. This, then, brings us to the role of local authority regarding ECD facilities and the more rigid stance of the urban regulatory framework.

\section{Early childhood development and the urban regulatory framework}

A rigid approach to community-based ECD facilities becomes clear when the role that local authorities are expected to fulfil within the current South African urban regulatory framework is considered. Local authorities are involved in the ECD scene in urban settings in different ways, inter alia through their general responsibility for orderly development, town planning and infrastructural development in towns and cities. This involvement includes the responsibility for spatial planning and managing of zoning schemes, application of building regulations, approval of building plans and issuing of land rights and fire safety certificates, application of health related regulations, and issuing of health clearance certificates (City of Cape Town 2013:9-10).

Important insight into the type of issues that local authorities have to deal with as custodians of orderly urban development, can be gained from a closer look at, for example, the South African National Building Regulations (Department of Trade and Industry 2008) and how they are interpreted in the South African National Standard (SANS) (SABS 2010). The standards that local authorities have to apply are much more exact and rigid than the standards set in the regulations of the Children's Act. To be fair, it should be noted that the stipulated requirements in the building regulations are not totally insensitive to the strenuous conditions that prevail in less developed communities. This becomes evident, for instance, in the current version of SANS, where the following is stated:

A new category of buildings ... has been introduced in certain classes of buildings that have a floor area not exceeding $80 \mathrm{~m}^{2}$ to make buildings affordable to poorer communities. The revised SANS 10400 allows choices to be made in the performance requirements of certain attributes for buildings falling within this category. Such buildings have comparable safety standards with buildings not so categorized, but may, depending upon the choices exercised in respect of particular attributes, have different resistances to rain penetration, deflection limits, maintenance requirements, lower levels of natural lighting, etc. (SABS 2010:2) 
While the above concession statement can be appreciated, it is followed by very definite technical prescriptions that remain difficult, if not impossible, to comply with within communities of the poorest of the poor (see SABS 2010:5-11). This difficulty of compliance already becomes quite apparent from the following qualification that directly follows this concession:

It should, however, be stressed that choices exercised in respect of these buildings relate only to the performance of some of the attributes of such buildings. The nature of developments is determined by environmental and town planning processes which are independent of such choices. This should be kept in mind by any local authority when assessing a building in terms of these revised functional regulations. (SABS 2010:2)

With this qualification, the full local regulatory complex related to land use and zoning, local economic development strategies, environmental issues, road hierarchy and transport corridors, and health and safety - is brought into play. From the point of view of orderly government all of this is well understood. And yet, the net effect of all of this is that it becomes impossible for most of the facilities under consideration to successfully apply for registration, which results in the inevitable criminalisation of the affected ECD services.

\section{Current policy development processes}

At the request of the Department of Social Development a process to upgrade policy on ECD management is currently underway. A 'policy report' that identifies issues and indicates the way forward in the policy process was as a result recently published (Martin et al. 2014a; Martin et al. 2014b). ${ }^{1}$ In the report the harshness of local authority standards is specifically mentioned as a factor that prevents facilities with good potential to register and to operate legally under social development law (Martin et al. 2014a:81; Martin et al. 2014b:42). The report acknowledges the more lenient nature of social development standards (Martin et al. 2014b:42), but also continues to explicitly mention the rigidity of local government standards when it states in respective points:

Onerous, and at times inappropriate infrastructure norms and standards prevent the registration of ECD programmes such as playgroups and centres that do not meet the prescribed standards. This in turn prevents access to subsidy funding which is a necessary, and often the only source of funding for improving infrastructure. (Martin et al. 2014a:70)

Norms and standards for ECD centres are generally reasonable. The main problem is the application of the inappropriately rigid municipal health and safety bylaws. In trying to ensure high standards of care, the net effect is that children are often unsupervised in home circumstances that are even more hazardous. (Martin et al. 2014b:42; Martin et al. 2014a:81)

To identify the unrealistic standards set on local government level can be an important step towards recognising the 'right to self-help' for communities and their informal ECD facilities. However, on closer investigation this recognition does not really seem to reflect in the policy report. Instead,

1.The policy report consists of a short, summarised report, and the full report. In this article both texts are used as sources. one finds evidence that the report is in fact heading in a direction that will even make the currently relatively lenient social development environment harsher for the informal ECD facilities. For instance, the report comments that across the world, including South Africa, 'governments have not invested enough in early childhood development programmes to ensure universal availability, equitable access and quality so as to realise the inherent developmental returns of ECD investments' (Martin et al. 2014b:28; cf. Martin et al. 2014a:61).

Yet, the truth is that the lack of governmental investment is most probably never going to change, except perhaps for a few marginal improvements. This 'truth' is, however, never recognised or raised as an issue in the report. Instead, one encounters in this report resemblances of a 'wealth-isthe-only-panacea' discourse when a statement is made in one place that ECD policies and programmes 'are effective only if funding is available' (Martin et al. 2014a:61; Martin et al. 2014b:28); in another place that '[s]ecuring universal availability and equitable access to ECD services will require a substantially larger investment of public funds in ECD programmes than is currently the norm in South Africa' (Martin et al. 2014a:62; cf. Martin et al. 2014b:29); and in another place, that an inevitable link exists 'between poor and inadequate infrastructure and the provision of poor quality ECD services' (Martin et al. 2014a:68; Martin et al. 2014b:33).

By suggesting that money becomes a precondition for good service, and by implication that the work of those with incredibly low budgets and little infrastructure is by definition of 'poor quality', large numbers of dedicated persons and effective institutions are dishonoured and declared 'undesirables'. Furthermore, this impression that 'low-budget-little-infrastructure' community initiatives could be labelled as 'undesirables' is strengthened in the report when it concedes that government cannot do it alone and that in order 'to make the Essential Package universally available, government must draw and build on the capacity of, and collaborate with, the relatively well-developed forand non-profit ECD community' (Martin et al. 2014a:59; Martin et al. 2014b:26). This, in effect, indeed excludes many of the 'relatively less developed' facilities that this article reports on from the future of government's policies and strategies.

\section{Informality, development rhetoric and early childhood development}

The reason for the requirement to comply with the municipal regulatory framework as a precondition for the formal registration of an ECD service under social development legislation seems self-evident and justified: until the real situation of facilities in poverty-stricken areas is placed under the magnifying glass. The actual situation in such areas is that the vast majority of buildings or dwellings are not in compliance with the high first-world standards applied by municipalities: not as a result of neglect but 
because the resources for improvement just do not exist. Although it is accepted that the presence of non-approved houses and businesses is not ideal, the fact is they are there and their existence is tolerated in many areas. If lower standards of housing and local business are tolerated in those communities because there are no alternatives, it seems reasonable to conclude that a similar tolerance of less formal ECD services in the same communities should be part of the wider 'package of tolerance'.

Against the background of such evaluative reflection, a recent study by Marie Huchzermeyer is helpful in providing language and terminology that assist in the identification of the problem. Her study entitled Cities with 'slums': From informal settlement eradication to a right to the city in Africa (Huchzermeyer 2011), takes an overtly critical stance against a discourse on 'development' in the international urban development environment. The background of the study is Target 11 of the United Nations Millennium Development Goals, which has found its inspiration in the 'Cities Without Slums' initiative of the multilateral organisation, Cities Alliance, with a target to achieve a significant improvement in the lives of at least 100 million slum dwellers globally by the year 2020 .

Huchzermeyer finds important reason in her study to problematise the idea of 'slum free cities'. She accordingly labels this idea as 'slum discourse', which, she furthermore argues, became a sub-theme in mainstream 'development' rhetoric (or discourse) in which 'vast numbers of people are effectively labelled as "undesirables"' in cities (Huchzermeyer 2011:1, 2). She argues that there is a 'heavily lopsided global-local contest over land-related opportunities', which effectively works towards the expulsion of the poor from the city. Applying this reasoning to the continent of Africa, she further argues:

This contest finds a biased and sustaining agency in most African countries' political elite, working not in favour of the local (let alone the poor), but of the global. For this elite, a liberal, corporate inspired conceptualisation of cities as competing commercial entities in need of brands, gateways, icons and global standards, reinforces the urgency of the perceived need to free cities of 'slums'. Within the development discourse poor people's responses, alternatives or innovations have been homogenised and problematised ... and 'translated' into a war on the poor. (Huchzermeyer 2011:3-4)

In the final analysis the question therefore becomes: 'If "cities with slums" are to be turned into "cities without slums", what is to become of Africa's "slum cities" - are they wished away altogether?' (Huchzermeyer 2011:7)

For Huchzermeyer, whilst the 'cities without slums' agenda is supposedly working in favour of the poor or 'slum dwellers', it in effect alienates and degrades them into 'undesirables' who somehow just have to disappear; and, by implication, whose self-help responses and innovations are degraded to the problems that need to be attacked and removed. In this way the (neo-liberal) agenda of 'development' reveals an inherent lopsided adherence to 'global standards' that cannot be complied with (Huchzermeyer 2011:3). This effectively send out only one message to those who cannot comply: you have no right to the city! (cf. Sharma 2000:120-124).

It can be argued that a discourse similar to the 'development' rhetoric of 'slum eradication in the interest of urban competitiveness' also underlies the 'cities without informal ECD centres' drive. This discourse, which can be referred to as a 'wealth is the panacea' discourse, seems to be embodied in policies and legislation, particularly in the legislation administered by local government. What is in effect happening, is that a hierarchy of problems is created in which the initiatives of the poor to care for themselves are degraded into 'the greater sin'. Moreover, government's inability to give full effect to its constitutional obligations towards children is recognised as a problem, but nevertheless tolerated. In contrast the initiatives and self-help innovations of communities to overcome the inefficiencies of government are not tolerated but targeted by policies and legislation, and actively threatened through administrative and policing measures.

\section{The story of a selection of informal child care facilities: Do they deserve to be deemed undesirable?}

The previous sections identified issues that are important for the future of ECD in South Africa. These can be summarised as follows:

- The provision of effective ECD services is essential for healthy community development.

- Governments worldwide do not find enough resources (funds, infrastructure, etc.) to sufficiently support this essential function. South Africa is no exception in this regard. There is not enough state funded resources to develop the ideal ECD dispensation.

- Many private community-based initiatives provide services in areas where people are poor and where very little funds and other resources are available. In spite of the challenges, these communities do their best with what little resources they have.

- Law and policies, however, seem to work from a development and wealth discourse that disqualify such efforts, declare them undesirable and personae non gratae in the country's ECD processes and strategies, and threaten them with closure and even prosecution.

The question now is: who are the people who are made into personae non gratae by the law? What do they do and what is their contribution? Are they really 'undesirables'? What is their true story?

The purpose of this section is to tell the story of some of those who, in terms of law and policy, are deemed undesirable. This is mainly done by drawing a statistical profile of the services they provide, based on a survey (Van der Walt \& Cronje 2012) that was done for the Centre for Contextual 
Ministry at the University of Pretoria in November and December 2012 in the Rustenburg/Phokeng area of the North West province. ${ }^{2}$ Despite the fact that the statistics and the responses of the managers of these facilities tell stories of suffering and despair, the emphasis is mainly on information that illustrates the resilience and hope displayed in the actions and services reported on (cf. Koopman 2009). The ultimate perspective of the section is that 'miracles' are being achieved by these carers with what little they have. As a result, it is argued that they should be cherished and supported as an important contributor to the ECD ideals of the country: not alienated, rejected and, even worse, prosecuted for the essential work they do.

\section{Definition}

The service providers in the conducted study referred to themselves as 'child minders'. This term is apparently used because most of them are not officially registered in terms of the South African regulatory system. In general usage, this term refers to persons looking after children in their own houses for payment, or to persons caring for the children of other people in the latter's homes.

A search with any search engine on the Internet will confirm this usage of the term child minder in the form of advertisements for positions that are more or less equal to that of a 'nanny' or 'au pair'. Such child minders will typically care for a small number of children. Should the service be for six or fewer children, the facility would be excluded from the requirement to register in terms of the Children's Act (The Presidency, Republic of South Africa 2008, Section 76).

In the case of the child minders of the municipal area represented in the survey, this term, however, points to a different reality. It is indeed used with reference to early childhood care facilities that are mostly not registered, but in these cases the number of children cared for would normally be significantly more than six, which would place them in the category of fully fledged ECD services that in terms of the Children's Act are actually supposed to be registered (The Presidency, Republic of South Africa 2008, Sections 76, 95). This article will therefore not refer to these services as 'child minders' but as ECD services of whom most are informal, that is, not registered.

\section{Context}

An important feature of the ECD services under discussion was the way in which they had established their own coordinating forum. This forum consisted of 35 member facilities at the time of the study, of which 31 participated in the survey. The facilities of the members were distributed over the whole area of the municipality in the study. Twenty of the 31 were located in townships, six in villages and five

in suburbs. ${ }^{3}$ The forum was not the only body representing ECD facilities, and the member facilities were obviously also not the only ECD facilities in the study area.

To put the aforementioned in greater perspective, the broader picture of the presence of formal and informal ECD services in North West province is relevant. Rough estimates of the presence of formal and informal ECD services in the province can be made based on the official figures provided in the strategic plan for 2009/10 - 2013/14 of the North West Department of Social Development, Women, Children and People with Disabilities (DSDWCPD). This document reported a baseline number of around 375000 children aged four years and younger in this province (DSDWCPD n.d.:13). Of this number, 83920 (approximately 22\% of the 375000 ) were cared for in 368 subsidised and registered ECD sites (DSDWCPD n.d.:40). This amounts to slightly more than 200 children per subsidised site on average. In addition to these subsidised sites, there were another 468 registered sites that were not subsidised (DSDWCPD n.d.:40). Assuming that these sites also cared for around 200 children each (which is a very high estimate), the total number of children in registered ECD facilities would not be more than about 177 500 or approximately about $47 \%$ of the total.

The strategic document also reported that the department was aware of the existence of another 860 unregistered sites (DSDWCPD n.d.:40). This stems from the fact that many of the sites that were not registered in terms of the Children's Act were registered with the Department of Social Development as Non-Profit Organisations (NPOs), which is a different registration with much less stringent requirements. According to the survey of the Centre for Contextual Ministry, there were on average 77 children per unregistered facility (Van der Walt \& Cronje 2012). If this number is extrapolated to the 860 unregistered facilities, it could be assumed, as a high estimate, that the department is aware of roughly another 66200 children in unregistered care facilities. Thus, the number of children of North West province in facilities that the department is aware of, cannot exceed 244000.

The above-mentioned figures mean that not more than approximately $65 \%$ of the 375000 young children in North West province can be accounted for in terms of their participation in ECD processes, either formal or informal. It is not clear what progress has been made since these baseline figures were published, but it can be assumed that the current position will not be significantly different from that reported above. This represents a major backlog, and with government finances that are already hugely stressed,

3.This distinction between different locations in the study area is made in accordance with a conceptual differentiation provided by Statistics South Africa. 'Township' according to this differentiation, refers to an urban residential area or settlement that was historically created for black migrant labour, usually beyond the town or city limits. In addition a distinction is also made between 'black township', 'coloured township' and 'Indian township', meaning that such settlements were created for township' and 'ndian township', meaning that such settlements were created for these population groups. By contrast, 'suburb' refers to a residential area within the boundaries of a town or city that, historically, has been occupied by white people but that may have become somewhat more integrated in the post-apartheid dispensation. Lastly, 'village' refers to a settlement in a tribal area that encompasse not only populated areas, but also agricultural areas (e.g. grazing land, crop land or forested land). In terms of a further understanding, villages usually fall unde the jurisdiction of tribal authorities, headed by chiefs and sub-chiefs (Statistics SA 2004:15, 16). 
it could well be accepted that this position will not improve significantly in future.

\section{Profile of the informal facilities}

The following profile elements were assessed as part of the research (Van der Walt \& Cronje 2012):

\section{Buildings}

Although most buildings were brick and mortar, the buildings of all facilities in the study were what could be described as 'very modest' to 'poor' (Table 1-A1). None of these facilities could be described as 'of high standard'. Some of the facilities were also used as the houses of the owners, whilst a few of the buildings were dedicated ECD facilities. None complied with the regulations for ECD facilities and most not even with the building regulations for normal houses. As far as could be established, none of the sites were rezoned for use as early learning centres.

\section{Size of play areas and number of classrooms}

During the survey the exact measurements of the inside play areas were not measured. The impression by observation was that most of the facilities were significantly more crowded than the official requirement of 1.5 square metre per child. In most cases, however, the classes seemed to function quite well in spite of them being moderately overcrowded (Table 2-A1). In a few cases the crowdedness of classrooms could be described as 'severe'.

During the survey the exact measurements of the outside play areas were also not measured. The impression was that the play areas of most facilities were adequate to slightly overcrowded, although the official requirement of 2 square metres per child was clearly not achieved in most cases. Only in three cases the researchers (in their capacity as observers) felt that the outside play areas were so overcrowded that play was seriously impeded.

\section{Kitchen and office spaces}

Twenty-four of the 31 facilities had their offices in rooms separated from the class rooms and inside play areas, whilst most of the remaining facilities seemed able to, with small rearrangements, adhere to official requirements regarding kitchen and office separation from play areas.

All the facilities did cooking for the children. Most had their cooking facilities in separate rooms. Cooking facilities appeared very modest, but care was taken to do cooking in a way to prevent children from being exposed to danger. Gas was used at $18(58 \%)$ of the facilities for cooking (one facility combined gas with paraffin, one used gas in combination with wood, and two used gas in combination with electricity). The rest used electricity.

\section{Furniture, equipment, toys, books and posters}

With regard to furniture, the focus of the evaluation was whether the items needed by the children were provided in adequate numbers and whether they were serviceable. In many cases the furniture for the children was of quite good quality, although modest. The same was found with regard to the availability of educational toys, books and posters. Several of the facilities however suffered serious shortages. Table 3 in Appendix 1 reflects the impressions of the researchers.

\section{Water and sanitation}

A large majority of the facilities (91\%) had running water on the premises. The rest had to fetch water from a tap in the street.

For washing of hands, $70 \%$ had basins with running water, $24 \%$ used washing bowls or buckets, and $6 \%$ did handwashing directly under a tap.

Only three facilities (9\%) did not have access to flush toilets, and used pit toilets instead. Twenty-three of the facilities also used potties. Many of the toilets were adequate, but there were a significant number of facilities where the standard of the toilets needed to be improved substantially (Table 4-A1).

\section{Gate safety}

Twenty-nine of the 31 facilities had gates that could be locked during the day, one gate was under construction, and in one case there was no lock while the owner reported that the 'teachers ensure safety'. During the survey it was difficult to evaluate what actual practices were applied to ensure the safety of children when picked up by parents or caregivers.

\section{Meals and snacks}

Breakfast and lunch were provided to the children at all facilities. Midmorning snacks were provided by only two of the facilities, whilst mid-afternoon snacks were provided in $90 \%$ of cases.

Evaluation of the meals, snacks and recipes was done from a non-exert perspective. In the view of the researchers the food in all cases (breakfast and lunch) was modest but healthy and well prepared. Breakfast was mostly porridge (maize). Lunch was of a good variety. Snacks were deemed 'healthy' by the researchers.

Meals were in all cases funded from the (mostly meagre) school fees. Five of the facilities $(16 \%)$ also received a government subsidy.

\section{Age divisions in classes}

Official standards require that children of different ages be accommodated in different groups and classes (Department of Social Development 2010:110-111). From the research it became clear that a serious attempt was made to comply with the formal requirements regarding the division of classes per age groupings (Box 1-A1). 
More than 2200 children were cared for by the 29 facilities that provided information, with virtually no support from government.

\section{Staff to children ratios}

Although the ratios were in some cases slightly lower than prescribed, the classes were not exceptionally large. Individual and personal attention to children seemed to be possible in most cases (Table 5-A1).

\section{Levels of training of staff}

Given the informal status of the facilities, the level of staff training was surprisingly high (Table 6-A1). However, respondents indicated the need for basic training, especially for the 51 out of $108(47 \%)$ staff members working directly with the children and who had no formal training. Training needs reported by the respondents included the following:

- General training in ECD, including on how to prepare and implement daily class programmes.

- Training related to the challenges of meeting the different development stages of children, preparing children for school readiness, rendering emotional support to children, addressing differences in children, and so on.

- Training in first aid, bookkeeping and financial management for managers, office administration, computer literacy and basic computer skills, time management and healthy cooking.

\section{Curriculum and daily programme}

Main contributing factors to the effectiveness of an ECD facility in preparing young children for the next level of schooling and for life, is a setting of care, emotional warmth and unconditional love; exposure to a variety of age appropriate stimulating experiences; honouring of the principle that a child learns through play; and respect for boundaries. These aspects are the essential ingredients of a successful programme and not in the first place the availability of expensive, first-world buildings and equipment as the 'wealth is the panacea discourse' propagates (cf. Perry 2002:97).

The good news is that the elements above can be provided and that they are indeed provided by many informal ECD facilities. Discussions during the survey with managers of some of the ECD facilities and observations made at their facilities revealed that good programmes were presented at facilities exposed to the same financial and resource related challenges as those where mediocre programmes were presented (Table 7-A1). The difference was not in the first instance brought about by funds and facilities, but by initiative and commitment, supported by relevant training and mentoring processes (cf. see Adams 2012).

\section{Sources of funding}

Most of the facilities in the study functioned without government support. Although none of the facilities were formally registered, five of the 31 facilities $(16 \%)$ did receive a bit of financial assistance from government (Table 8-A1).

Another noticeable feature was the way in which the services succeeded to operate on a low fees structure, which corresponded with the financial position of the surrounding communities (Table 9-A1). By allowing the ECD facilities to offer their programmes at service levels that corresponded with the financial status of their surrounding communities, the communities were in turn able to invest what meagre financial resources they had in the future of their children. This should be respected and supported, not slighted and threatened.

A valuation of the fee structure should be done with due consideration of the long working hours and the extent of services: many of the ECD facilities started receiving children already before 07:00 and kept them until late in the afternoon, five days per week. Against this background the fees seemed low in comparison to the services rendered. At the same time, the total amount invested by the communities into their own community-based programmes proved to be significant. An estimated R600 000 per month (between R7 million and R8 million per annum) was invested by these communities in the community-based ECD services they initiated and developed. This proves that the communitybased, independent ECD 'industry' is not an insignificant entity that could be slighted, ignored and written off in high level policies and in legislation that is unrelated to the realities on grass roots level.

\section{Management and governance structures}

Although the informal ECD facilities under discussion do not have any hope to be formally accepted and registered under the current legislative and policy dispensation, the survey revealed that most had done their homework well and had introduced the management measures required by the Children's Act. This included that 20 of the facilities had instituted 'School Governing Bodies' (SGBs) as part of their management structures, in compliance with the national standards for ECD facilities (The Presidency, Republic of South Africa 2008, Section 90(f); Department of Social Development 2010:28).

\section{General impressions}

In the survey general impressions were also recorded in terms of cleanliness and neatness of facilities, organisational processes and the professional levels of the service providers (Table 10-A1).

\section{Contributions and challenges}

In asking facilitators and managers of the represented ECD services to share their opinions on how they saw the contribution of their services to their respective communities, their answers alluded to the way in which their services were keeping children off the street, providing secure care 
for them; preparing them for school, developing their skills, creating employment, ensuring that children receive a balanced meal, developing them physically and emotionally, bringing stability in their lives, and creating awareness and training regarding care for children with disabilities.

When asked why parents enrolled children at the ECD facility, most facilitators and managers reported that working parents needed someone to care for their children. One reported that only about $20 \%$ of parents were working, while the rest were unemployed. Fifteen (48\%) of the respondents mentioned that parents brought the children to the ECD facility because they believed that the children would be well-developed.

Facilitators and managers were also asked about the main challenges they were facing. Financial difficulties were reported by most facilities. This was mainly as a result of parents who did not pay the fees for their children, or who paid late. Other challenges included an inability to comply with local government requirements; challenges regarding rezoning and the non-availability of suitable land; low levels of parent involvement and lack of parent interest; ignorance of parents on certain aspects of child development; language factors, as some children were not from the local area (including foreign nationals) and therefore did not speak Setswana, the most spoken local vernacular; lack of government funding; non-payment of approved grants by the Department of Social Development (the manager of one of the few subsidised facilities reported: 'Because the social grants have not been paid for the last eight months it is difficult to buy all the food'); children not behaving well; facilitators ('teachers') undermining management; lack of commitment by facilitators; unqualified facilitators; inadequate space; and insufficient play equipment.

The personal stories of the owners and facilitators were heart-rending: for example that of the owner of the best performing facility of the group. She had no education except for a low grade at school, and was working as a 'house assistant' (cleaner) in a suburban home. She came under the impression of the dire need of little children in the immediate surrounding area of her small house in one of the townships. This prompted her to enrol for training whilst starting with a childminder group. She continued training until she qualified on National Qualifications Framework (NQF) Level 5. With no government funds she transformed her house into an ECD facility, and then added a 'tin shack structure' to increase capacity. Needless to say, all of this was illegal in terms of the local government standards regarding building regulations and the local zoning scheme. For this reason she could not register her facility. And yet, the programme presented at her modest facility was of a high standard and provided a commendable service to the children and employment to several staff members on different levels (facilitators, assistants, a cook and a cleaner). She and her personnel with her tiny 'shack'-based ECD facility were clearly a lighthouse of hope in the immediate community. But in terms of urban regulations and policies she ran the risk of being prosecuted for rendering this well-run, selfless service to children who would otherwise be roaming the streets without care.
Another story worth recalling is about one of the owners of a well-developed informal facility that could not be registered because of zoning problems. She recalled the way in which she approached the municipality with the request that a re-zonable stand be made available to her facility in an area where new low cost housing had been provided. The response was merely that the municipality needed the stand for houses and not for a school: end of story. As a result she continued illegally with no hope of finding a way to operate within the law.

\section{Towards an appropriate urban public theological response}

When considering the information provided thus far in this article, it is clear that there is no simple solution. The different spheres of government have responsibilities in terms of orderly government that cannot be denied. They can, and should, be expected to perform their duties well and in accordance with the prescribed standards they work towards.

However, something is clearly wrong when, as a result of governmental regulations, children are denied their right to proper care and development during the critical first few years of their lives. If communities that want to take initiative and address these problems are disallowed to do so, serious questions have to be asked. If the work of great-hearted people on grass roots level stands in consistent danger of being closed down, and if they are prosecuted for the work they do in the interest of the most vulnerable children in the community, by giving such children at least some access to educational opportunities and safe space, then voices have to be raised to articulate the injustices in the way our laws and policies function. If it is found that the urban regulatory system is a major contributor to this intolerable state of affairs, then bold action is needed to change the way our cities function with regard to early childhood matters.

What should be done to address the current challenges? This is a complex matter with no easy answers. There are, however, a few things that are clear. The solution should include that the societal mind that allows these things to happen, and approve of it as 'good governance' and 'responsible development', be changed. The grand narratives or discourses underlying the offensive elements in the regulatory system and the administration thereof need to be identified, exposed and deconstructed to reveal the extent of their contribution to serious injustices to the most vulnerable.

There are obviously different institutions in society that need to attend to these matters. The point of the present article is that the Church of Jesus Christ should be one of them and that it, if necessary, should play a leading role in this regard. The Church confesses itself as the present body of Jesus of Nazareth (Eph 1:21). This is the Jesus who said 'let the little children come to me, and do not hinder them, for the kingdom of heaven belongs to such as these' (Mt 19:14, NIV Bible 2011). 
It is the task of a responsible public theology and the Church to be relevant where injustices to 'the little children' prevail. As such, an urban public theology should operate in the modes identified in the first main section of this article to develop the motivation, language and skills that will enable the Church to effectively address these matters. Within such a framework and by way of a first reflection, this article now closes with some more pertinent ideas on what an appropriate urban public theological response to such agenda should entail.

Public theology should not only assist churches towards a better understanding of the role of ECD to individual human development, but also to the integral contribution of this function to overall societal wellness, community development and the upholding of human rights. In theological terms, this should lead churches to understand their engagement in the terrain or field of ECD as an exceptionally meaningful opportunity to participate in the missio Dei and, through such participation, contribute towards the creation of a comprehensive condition of shalom. As indicated earlier, an understanding of the importance of ECD has become a discourse in the societal mind of South Africans. Public theology, on its part, needs to involve itself with the refinement of this discourse so that the content thereof as well as the practices deriving from such content should reflect a healthy understanding of this function.

Public theology should critically examine the way in which the regulation of ECD is embodied in legislation, policies and governmental practices, how it impacts on the lives of children and parents, and how the right of grass roots communities to apply their own initiatives and innovations to take care of their future and that of their children is respected.

In the discussion earlier in this article it was pointed out how resource-poor communities with inadequate government supported ECD services are being denied the right to apply their own initiatives for the good of their children and the wellness of their communities. It was suggested that the regulatory framework, at least to the extent that it is applied to ECD facilities in informal settlements and other resource-poor communities, was substantially influenced by 'wealth discourses' that correlate with the international, first-world driven 'development' and "slum" discourses'. An urban public theology should provide churches with an understanding of the situation as well as the language or 'conceptual tools' to deal with this, by deconstructing those discourses and indicating alternative directions that government's thinking, policies and practices need to take.

Identification of the underlying discourses and the alternative futures that need to be developed within the ECD domain, calls for further urban public theological labour and ecclesial practices. And it is in view of this anticipated public theological task that it becomes necessary and important to return to the valuable fivefold distinction of Koopman on how public theology should go about its task in present-day South African society in a faithful and credible way. The following concluding points represent a first attempt, on the basis of this article's focus on the contextual challenge of
ECD in present-day South Africa, to start a conceptualisation along the lines of that fivefold distinction.

\section{Vision of the good society}

Following on this article's deconstruction of the sociocultural discourses on ECD that determine the current South African societal mind, the future of ECD in South Africa should not only be envisaged in terms of the involvement of government and the already existing well-provisioned ECD services. The vision should be one of an inclusive future where the initiatives and innovations of grass roots communities will be embraced as important and respected contributions to a comprehensive ECD strategy for the country. This is a vision where government, the well-provisioned ECD services, the more modest community initiatives, and churches as supporting institutions, will, to the best of their ability, jointly invest in the well-being of the most vulnerable of our communities.

\section{Criticism}

There is serious injustice in criminalising 'lighthouses of hope' in the community and through this denying the most vulnerable - 'the little children' of poverty-stricken communities - the opportunity of a reasonable, if not good, educational foundation. This is all the more unjust if such criminalisation is based on a 'wealth discourse' that is inappropriate to the contextual realities of resource-poor communities. A faithful and credible public theology should stand on the side of those who are the objects of regulatory and administrative injustices - and also empower churches to follow suit - by offering an irrefutable analysis of the situation and the underlying discourses, by communicating this to audiences that matter, by practically assisting the informal ECD services to upgrade the services as close as possible to the reigning standards, and by stepping into the breach for those services when they stand to be closed down and prosecuted for the good work they do. These acts of solidarity should be persevered with even if it implies engaging in a form of civil disobedience in the process.

\section{Technical analysis of public issues}

Technical analysis, as part of an urban public theological response to the current challenges in the ECD sector, should begin with an in-depth analysis of the socio-economic motives and discourses that underlie the regulatory and administrative frameworks grass roots communities are subjected to. This should lead to the point where those in power will be confronted with the liberating motives of hope, life and trust that lie at the core of the Jesus narrative. Moreover, technical analysis should go further by ensuring that the hard facts of the urban environment and the industry under consideration be analysed and presented in a way that will, in an uncompromising way, reveal the negative impacts of prevailing policies and point the way to viable alternatives.

\section{Telling stories of suffering and despair but also of resilience and hope}

By telling the stories of ECD facilities such as those reported on in this article, the faceless, ignored and side-lined, will 
begin to appear as real people who render a professional service and act as 'lighthouses of hope'. It is easy to disqualify a faceless, unknown entity. At the same time it is, however, difficult to discard real people, especially those who are revealed as loving, caring and professional and who toil on a daily basis to give at least some kind of future to otherwise futureless and vulnerable creatures born in the image of God. It is the task of an urban public theology to go out and find these stories, and to make them speak not only to those in the Church and other normatively orientated environments, but also to those who have the power to make a difference.

\section{Participating in policy-making and policy- implementing processes}

Steered by a realistic vision, but also by faith, hope, love, real-life stories and scientifically sound analysis and argumentation, an urban public theology should strategically position both itself and the broad ecclesial community to engage in active policy processes: and, where necessary, to work for the reopening of particular policy processes as suggested by the critical discussion in this article.

Theology and the ecclesial community should not merely be talking. In so far as the challenges of ECD are concerned in present-day South Africa, churches are well resourced and geographically positioned to make a considerable contribution towards the provisioning of ECD services, and to, in this process, support both government and the informal ECD community. So many churches have connections that could assist, facilities that could be used for, and resources that could support the implementation of ECD strategies in grass roots communities. If they are serious about the future of 'the little ones' Jesus loves, many more churches will tap into their own networks, facilities and resources to soften the heavy burden that rests on the shoulders of government and informal service providers. Developing the motivation for such involvement and guiding the process thereto should form part of the policy implementation responsibility of an urban public theology.

\section{Acknowledgements}

For the purpose of ethical clearance, persons interviewed in this research or in any way became involved as 'coresearchers' as a result of their interaction with the authors, remain anonymous. The authors declare that everything possible has been done to maintain confidentiality.

\section{Competing interests}

The authors declare that they have no financial or personal relationship(s) that may have inappropriately influenced them in writing this article.

\section{Authors' contributions}

J.P.v.d.W. (University of Pretoria) conducted the original empirical work reflected in the article and wrote an initial draft. I.S. (University of South Africa) and S.d.B. (University of Pretoria) made substantial conceptual contributions and were both responsible for the revision of the article. I.S. contributed as author to the final text and prepared the article for submission.

\section{References}

Adams, G., 2012, 'Namkids program for informal community based ECD facilities in Katatura, Windhoek', unpublished course material, August.

Bons-Storm, R., 1996, The incredible woman: Listening to women's silences in pastoral care and counselling, Abingdon Press, Nashville, TN.

City of Cape Town, 2013, Early childhood development policy, viewed 10 April 2014 from http://www.capetown.gov.za/en/PublicParticipation/Documents/ECD\%20 POLICY\%20updated\%20on\%2002\%20April\%202013.pdf

Constitution of the Republic of South Africa No. 108 of 1996, viewed 15 April 2014 from http://www.gov.za/documents/constitution/1996/a108-96.pdf.

Department of Social Development, 2010, 'Consolidated regulations pertaining to the Children's Act 2005', Government Gazette, No. 33076, viewed 09 May 2014, from http://www.lexisnexis.co.za/pdf/DSD-Consolidated-Regulations-GG-2010-04-01 No-33076-Part1.pdf

Department of Social Development, Women, Children and People with Disabilities (DSDWCPD), n.d., Strategic plan 2009/10 - 2013/14, viewed 12 April 2014, from http://www.nwpg.gov.za/dsdwcpd/documents/Social\%20Development\%20 Strategic\%20Plan\%202.pdf

Department of Trade and Industry, 2008, 'National building regulations', Government Gazette, No. 31084, viewed 05 June 2014, from http://www.greengazette. co.za/documents/regulation-gazette-31084-of-30-may-2008-vol-515-no8895_20080530-GGR-31084.pdf

De Villiers, E. \& De Beer, S., 2009, 'Van verhaal tot beleid: Die kerk se verantwoordelikheid ten aansien van arm mense in Nederland en Suid-Afrika ' $n$ Verantwoordelikheidsetiesebenadering', in F.G. Immink \& C. Vos (reds.), God in ' kantelende wêreld, bl. 109-134, Protea Boekehuis, Pretoria.

Huchzermeyer, M., 2011, Cities with 'slums': From informal settlement eradication to a right to the city in Africa, UCT Press, Cape Town.

Koopman, N., 2009, 'Public theology as prophetic theology: More than utopianism and criticism?', Journal of Theology for Southern Africa 133, March, 117-130.

Martin, P., Berry, L., Biersteker, L., Desmond, C., Harrison, D., Naicker, S. et al., 2014a 'Early childhood development: National ECD policy', draft full report on Nationa ECD Policy, Human Sciences Research Council, viewed 12 February 2014, from http://www.itec.org.za/wp-content/uploads/2014/03/ECD-Policy-LONG-REPORTDRAFT-28-February-2014.pdf

Martin, P., Berry, L., Biersteker, L., Desmond, C., Harrison, D., Naicker, S. et al., 2014b, 'Early childhood development: National ECD policy', draft short report on Nationa ECD Policy, Human Sciences Research Council, (hard copy obtained).

Mercer, N., 2004, 'Sociocultural discourse analysis: Analysing classroom talk as a social mode of thinking', Journal of Applied Linguistics 1(2), 137-168. http://dx.doi. org/10.1558/japl.2004.1.2.137

National Planning Commission, 2011, National Development Plan 2030: Our future make it work, The Presidency, Republic of South Africa, viewed 17 March 2014 from http://www.npconline.co.za/MediaLib/Downloads/Downloads/NDP\%20 2030\%20-\%200ur\%20future\%20-\%20make\%20it\%20work.pdf

Perry, B.D., 2002, 'Childhood experience and the expression of genetic potential: What childhood neglect tells us about nature and nurture', Brain and Mind 3 , 79-100. http://dx.doi.org/10.1023/A:1016557824657

Richter, L., Berry, L., Biersteker, Harrison, D., Desmond, C., Martin, P. et al., 2014, 'Early childhood development: National EDC Programme', draft full report on the National ECD Programme, Human Sciences Research Council, viewed 12 February 2014, from http://www.itec.org.za/wp-content/uploads/2014/03/ECDProgramme-LONG-REPORT-DRAFT-28-February-2014.pdf

Sharma, K., 2000, Rediscovering Dharavi: Stories from Asia's largest slum, Penguin Books, New Delhi.

South African Bureau of Standards (SABS), 2010, 'South African National Standard (Edition 3): The application of the National Building Regulations: Part A: General principles and requirements', SABS Standards Division, viewed 05 June 2014, from https://law.resource.org/pub/za/ibr/za.sans.10400.a.2010.pdf.

Statistics South Africa (Stats SA), 2004, 'Census 2001: Concepts and definitions, Report no. 03-02-26, Version 2', in Statistics South Africa, viewed 18 April 2014, from http://www.statssa.gov.za/census01/html/concepts\%20\&\%20definitions.pdf

Swart, I. \& Yates, H., 2006, 'The rights of children: A new agenda for practical theology in South Africa', Religion \& Theology, 13 (3/4), 314-340.

The Presidency, Republic of South Africa, 2008, 'Children's Amendment Act No. 41 of 2007', Government Gazette, Vol. 513, no. 30884, viewed 12 April 2014 from http://www.polity.org.za/article/children039s-amendment-act-no-41of-2007-2008-04-10

Van der Walt, J.P. \& Cronje, S.A., 2012, 'Study of thirty-one informal ECD facilities in an urban environment: Unpublished data set', Centre for Contextual Ministry, University of Pretoria, November and December.

Yates, H., 2012, 'Die promovering van kinderregte: 'n Prakties-teologiese ondersoek', DTh dissertation, University of Stellenbosch, viewed 22 May 2014, from http:// scholar.sun.ac.za/handle/10019.1/71759 


\section{Appendix 1}

All the tables and one box presented in this Appendix have been compiled on the basis of the data that were generated by the research of Van der Walt and Cronje (2012) in the Rustenburg/ Phokeng area of North West province. The intention in each case is to give a summarised or synthesising view of the different elements that were assessed.

TABLE 1-A1: Construction material used for walls.

\begin{tabular}{lll}
\hline Material & Number & $\mathbf{\%}$ \\
\hline Bricks (some extended with tin 'shacks') & 27 & 87 \\
Tin & 3 & 10 \\
Tin and wood & 1 & 3 \\
\hline Total & $\mathbf{3 1}$ & $\mathbf{1 0 0}$ \\
\hline
\end{tabular}

TABLE 2-A1: Number of classrooms.

\begin{tabular}{lll}
\hline Classrooms per facility & $\begin{array}{l}\text { Number of } \\
\text { facilities }\end{array}$ & $\%$ \\
\hline 1 & 2 & 6 \\
2 & 9 & 29 \\
3 & 12 & 39 \\
4 & 4 & 13 \\
5 & 2 & 6 \\
6 & 1 & 3 \\
7 & 0 & 0 \\
8 & 1 & 3 \\
\hline Total & $\mathbf{3 1}$ & $\mathbf{1 0 0}$ \\
\hline
\end{tabular}

TABLE 3-A1: Standard of furniture, toys, books and posters.

\begin{tabular}{lllll}
\hline Standard & Furniture (\%) & $\begin{array}{l}\text { Equipment / } \\
\text { Toys (\%) }\end{array}$ & Books (\%) & $\begin{array}{l}\text { Posters and } \\
\text { children's } \\
\text { artwork on } \\
\text { walls (\%) }\end{array}$ \\
\hline $\begin{array}{l}\text { Well provided } \\
\text { Adequate }\end{array}$ & 3 & 3 & - & - \\
$\begin{array}{l}\text { Inadequate } \\
\text { Scarce / Not }\end{array}$ & 58 & 30 & 33 & 52 \\
available & - & 61 & 61 & 45 \\
\hline Total & $\mathbf{1 0 0}$ & 6 & 6 & 3 \\
\hline & & $\mathbf{1 0 0}$ & $\mathbf{1 0 0}$ & $\mathbf{1 0 0}$ \\
\hline
\end{tabular}

TABLE 4-A1: Availability of toilets.

\begin{tabular}{lll}
\hline Type of toilet facility & $\begin{array}{l}\text { Number of facilities with } \\
\text { this kind of toilet }\end{array}$ & $\begin{array}{l}\text { \% of facilities with this } \\
\text { kind of toilet }(\boldsymbol{N}=\mathbf{3 1})\end{array}$ \\
\hline Flush toilets & 28 & 90 \\
Potties & 23 & 74 \\
Bucket & 0 & 0 \\
Sand/grass & 0 & 0 \\
\hline
\end{tabular}

BOX 1-A1: Division of age groups and number of children.

\begin{tabular}{|c|c|c|c|c|c|c|c|c|}
\hline \multirow[t]{2}{*}{ Facility } & \multicolumn{7}{|c|}{ Combination of ages } & \multirow[t]{2}{*}{ Total } \\
\hline & 1 Year & 2 Years & 3 Years & 4 Years & 5 Years & 6 Years & 7 Years & \\
\hline 1 & \multicolumn{2}{|c|}{30} & \multicolumn{2}{|c|}{37} & 44 & 41 & - & 152 \\
\hline 2 & \multicolumn{2}{|c|}{15} & 12 & 14 & 4 & - & - & 45 \\
\hline 3 & \multicolumn{2}{|c|}{17} & \multicolumn{2}{|c|}{35} & \multicolumn{2}{|c|}{5} & & 57 \\
\hline 4 & \multicolumn{2}{|c|}{40} & \multicolumn{2}{|c|}{40} & - & - & - & 80 \\
\hline 5 & \multicolumn{2}{|c|}{6} & \multicolumn{2}{|c|}{26} & 65 & \multicolumn{2}{|c|}{9} & 106 \\
\hline 6 & \multicolumn{2}{|c|}{16} & 24 & 15 & \multicolumn{2}{|c|}{34} & - & 89 \\
\hline 7 & \multicolumn{4}{|c|}{32} & \multicolumn{2}{|c|}{36} & - & 68 \\
\hline 8 & \multicolumn{3}{|c|}{9} & 29 & \multicolumn{2}{|c|}{22} & - & 60 \\
\hline 9 & 18 & \multicolumn{2}{|c|}{27} & \multicolumn{2}{|c|}{24} & - & - & 69 \\
\hline 10 & \multicolumn{2}{|c|}{11} & \multicolumn{2}{|c|}{16} & 10 & - & - & 37 \\
\hline 11 & \multicolumn{7}{|c|}{ No information obtained } & \\
\hline 12 & 30 & & 1 & & 1 & 14 & - & 86 \\
\hline 13 & \multicolumn{2}{|c|}{13} & \multicolumn{3}{|c|}{17} & - & - & 30 \\
\hline 14 & \multicolumn{2}{|c|}{12} & 24 & 15 & & 0 & - & 91 \\
\hline 15 & 25 & & 0 & & 20 & & 29 & 364 \\
\hline 16 & 3 & 0 & 32 & & 0 & & 5 & 127 \\
\hline 17 & & & No info & rmation o & btained & & & \\
\hline 18 & 1 & 2 & & 4 & 18 & - & - & 44 \\
\hline 19 & 1 & 2 & & 0 & & 0 & - & 102 \\
\hline 20 & 5 & 5 & & 6 & 6 & 2 & - & 29 \\
\hline 21 & 16 & & 5 & 3 & 2 & & - & 73 \\
\hline 22 & 10 & & 4 & & 4 & - & - & 78 \\
\hline 23 & 6 & & 0 & & 5 & - & - & 41 \\
\hline 24 & 1 & 1 & & 3 & & 0 & - & 64 \\
\hline 25 & & 16 & & & 11 & & & 27 \\
\hline 26 & & 8 & & & 2 & & 3 & 28 \\
\hline 27 & 20 & & 2 & & 5 & - & - & 87 \\
\hline 28 & 10 & & 4 & & 1 & - & - & 45 \\
\hline 29 & 10 & & 3 & & 0 & - & - & 43 \\
\hline 30 & 2 & 0 & & 5 & - & - & - & 35 \\
\hline 31 & 14 & & 5 & 2 & 8 & - & - & 67 \\
\hline Total & & & & & & & & 2224 \\
\hline
\end{tabular}

TABLE 5-A1: Number of children and number of staff.

\begin{tabular}{|c|c|c|c|c|c|c|c|c|}
\hline Facility & Children & Managers & $\begin{array}{l}\text { ECD } \\
\text { practitioners }\end{array}$ & Class assistants & Cooks & Other & Total staff & $\begin{array}{l}\text { Average number of } \\
\text { children per manager, } \\
\text { practitioner and assistant }\end{array}$ \\
\hline 1 & 152 & 1 & 8 & - & 1 & 1 cleaner & 11 & 17 \\
\hline 2 & 45 & 1 & 2 & - & 1 & - & 4 & 15 \\
\hline 3 & 57 & 1 & 2 & 1 & - & - & 4 & 14 \\
\hline 4 & 80 & 1 & 4 & - & 1 & - & 6 & 16 \\
\hline 5 & 106 & 1 & 3 & - & 1 & 1 & 5 & 27 \\
\hline 6 & 89 & 1 & 3 & 2 & 1 & - & 7 & 15 \\
\hline 7 & 68 & 1 & 2 & - & 1 & - & 4 & 23 \\
\hline 8 & 60 & 1 & 2 & - & 1 & - & 4 & 23 \\
\hline 9 & 69 & 1 & 3 & 1 & 1 & - & 6 & 14 \\
\hline 10 & 37 & 1 & 3 & - & 1 & - & 5 & 9 \\
\hline 11 & - & 1 & 3 & - & 1 & - & 5 & 0 \\
\hline 12 & 86 & 1 & 3 & 3 & 1 & - & 8 & 12 \\
\hline 13 & 30 & 1 & 2 & - & - & - & 3 & 10 \\
\hline 14 & 91 & 3 & 3 & 2 & 2 & 1 gardener & 11 & 11 \\
\hline 15 & 364 & 2 & 2 & 10 & 3 & - & 17 & 26 \\
\hline
\end{tabular}


TABLE 5-A1 continues: Number of children and number of staff.

\begin{tabular}{|c|c|c|c|c|c|c|c|c|}
\hline Facility & Children & Managers & $\begin{array}{l}\text { ECD } \\
\text { practitioners }\end{array}$ & Class assistants & Cooks & Other & Total staff & $\begin{array}{l}\text { Average number of } \\
\text { children per manager, } \\
\text { practitioner and assistant }\end{array}$ \\
\hline 16 & 127 & 2 & 3 & 2 & 2 & - & 9 & 18 \\
\hline 17 & - & 7 & 4 & 4 & 2 & - & 17 & 0 \\
\hline 18 & 44 & 1 & 3 & - & 1 & - & 5 & 11 \\
\hline 19 & 102 & 1 & 3 & - & 1 & 1 cleaner & 6 & 26 \\
\hline 20 & 29 & 1 & 1 & - & - & - & 2 & 15 \\
\hline 22 & 78 & 1 & 1 & - & 1 & - & 3 & 39 \\
\hline 23 & 41 & 1 & - & 2 & 1 & - & 4 & 14 \\
\hline 24 & 64 & 1 & 1 & 1 & 1 & - & 4 & 21 \\
\hline 25 & 27 & 1 & - & 2 & - & - & 3 & 9 \\
\hline 26 & 28 & 1 & 1 & 2 & 1 & 1 cleaner & 6 & 7 \\
\hline 27 & 87 & 1 & 2 & 3 & 2 & - & 8 & 15 \\
\hline 28 & 45 & 1 & 1 & 2 & - & - & 4 & 11 \\
\hline 30 & 35 & 1 & 1 & 1 & - & - & 3 & 12 \\
\hline 31 & 67 & 1 & 1 & 4 & 1 & 1 cleaner & 8 & 11 \\
\hline Total & 2224 & 41 & 67 & 48 & 30 & 5 & 191 & 14 \\
\hline
\end{tabular}

ECD, early child development.

TABLE 6-A1: Levels of training of staff.

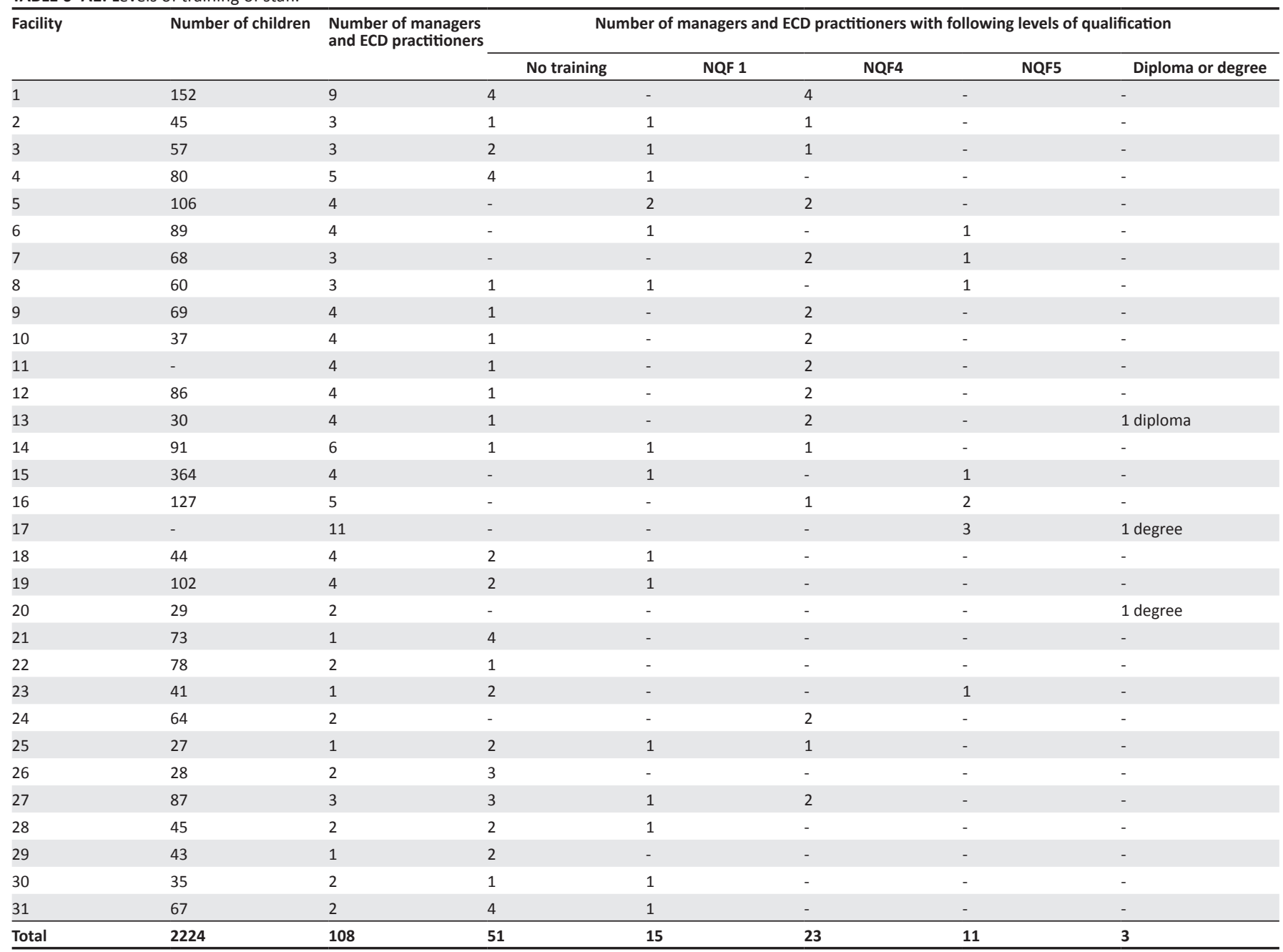

ECD, early child development; NQF, National Qualifications Framework. 
TABLE 7-A1: Curricula and daily programmes.

\begin{tabular}{|c|c|c|}
\hline Item & Number & $\%$ \\
\hline Formal curriculum used & 7 & 23 \\
\hline Formal daily programme used & 31 & 100 \\
\hline Daily programme includes Bible instruction & 16 & 52 \\
\hline Daily programme includes life skills/environment & 16 & 52 \\
\hline Daily programme includes numeracy/preparatory maths & 21 & 68 \\
\hline Daily programme includes preparatory reading/literacy & 22 & 71 \\
\hline Daily programme includes preparatory writing & 22 & 71 \\
\hline $\begin{array}{l}\text { Daily programme includes } \\
\text { music and singing }\end{array}$ & 18 & 58 \\
\hline Daily programme includes formal toilet routines & 31 & 100 \\
\hline Daily programme includes specific times for free play & 31 & 100 \\
\hline
\end{tabular}

TABLE 8-A1: Source of funds for the operation of the facilities.

\begin{tabular}{|c|c|c|}
\hline Source & Number & $\%$ \\
\hline School fees paid by parents & 25 & 81 \\
\hline School fees, supplemented by social development grants / subsidies & 5 & 16 \\
\hline Social development grants only & 0 & 0 \\
\hline School fees, supplemented by other grants and funds raised & 1 & 3 \\
\hline Total & 31 & 100 \\
\hline
\end{tabular}

TABLE 9-A1: School fees as in December 2012.

\begin{tabular}{|c|c|c|c|c|}
\hline \multirow[t]{2}{*}{ Range of monthly fees per child } & \multicolumn{2}{|c|}{ Lower ages group } & \multicolumn{2}{|c|}{ Higher age group } \\
\hline & $\begin{array}{l}\text { Number in } \\
\text { this range }\end{array}$ & $\%$ & $\begin{array}{l}\text { Number in } \\
\text { this range }\end{array}$ & $\%$ \\
\hline R151-R200 & 2 & 6 & 6 & 19 \\
\hline R201-R250 & 5 & 16 & 12 & 39 \\
\hline R251-R300 & 15 & 48 & 5 & 16 \\
\hline R301-R350 & 5 & 16 & 1 & 3 \\
\hline R351-R400 & 2 & 6 & - & 0 \\
\hline More than R400 & 2 & 6 & 1 & 3 \\
\hline Total & 31 & 100 & 25 & 81 \\
\hline
\end{tabular}

TABLE 10-A1: General impression of facilities as perceived by researchers.

\begin{tabular}{|c|c|c|c|c|c|c|c|c|}
\hline \multirow[t]{2}{*}{ Material } & \multicolumn{2}{|c|}{ High } & \multicolumn{2}{|c|}{ Medium } & \multicolumn{2}{|c|}{ Low } & \multicolumn{2}{|c|}{ Total } \\
\hline & Number & $\%$ & Number & $\%$ & Number & $\%$ & Number & $\%$ \\
\hline Clean & 10 & 32 & 20 & 65 & 1 & 3 & 31 & 100 \\
\hline Neat & 13 & 42 & 16 & 52 & 2 & 6 & 31 & 100 \\
\hline Orderly processes, well organised & 11 & 35 & 17 & 55 & 3 & 10 & 31 & 100 \\
\hline Level of operations, professionalism & 11 & 35 & 17 & 55 & 3 & 10 & 31 & 100 \\
\hline
\end{tabular}

